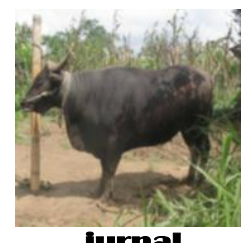

Jurmal FADET UNUD

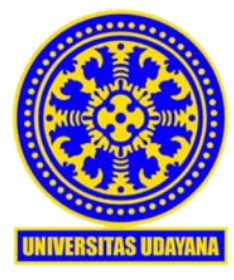

Submitted Date: Mey 3, 2020

Editor-Reviewer Article;: Eny Puspani \&2 A.A.Pt. Putra Wibawa

\title{
Pengaruh Penggantian Ransum Komersial dengan Tepung Limbah Kecambah Kacang Hijau Difermentasi terhadap Sistem Pencernaan Itik Bali Jantan
}

\author{
Maulana, A., I. M. Suasta dan D. P. M. A. Candrawati \\ PS Sarjana Peternakan, Fakultas Peternakan, Universitas Udayana, Denpasar, Bali \\ e-mail: akmalmaulana@student.unud.ac.id, Telp +6285257402177
}

\begin{abstract}
ABSTRAK
Limbah kecambah kacang hijau merupakan bagian dari kecambah kacang hijau yang sudah tidak dimanfaatkan lagi dalam proses produksi, bahkan biasanya terbuang sia-sia. Penelitian ini bertujuan untuk mengetahui pengaruh penggantian ransum komersial dengan tepung limbah kecambah kacang hijau difermentasi terhadap sistem pencernaan itik bali jantan. Penelitian ini menggunakan Rancangan Acak Lengkap (RAL) dengan tiga perlakuan dan lima ulangan. Perlakuan yang diberikan yaitu; P0 (ransum komersial 100\%), P1 (penggantian $12,5 \%$ ransum komersial dengan tepung limbah kecambah kacang hijau difermentasi) dan P2 (penggantian 25\% ransum komersial dengan tepung limbah kecambah kacang hijau difermentasi). Variabel yang diamati dalam penelitian ini adalah persentase berat tembolok, persentase berat proventrikulus, persentase berat ventrikulus, persentase berat hati, persentase berat pankreas, persentase berat empedu, persentase berat usus halus dan panjang usus halus. Hasil penelitian menunjukkan bahwa penggantian $12,5 \%$ dan $25 \%$ ransum komersial dengan tepung limbah kecambah kacang hijau difermentasi berpengaruh nyata $(\mathrm{P}<0,05)$ meningkatkan persentase berat tembolok dengan $\mathrm{P} 1$ dan $\mathrm{P} 2$ masing-masing sebesar $40,90 \%$ dan $86,36 \%$ lebih tinggi dari perlakuan ransum komersial 100\% (P0), tetapi berbeda tidak nyata $(\mathrm{P}>0,05)$ terhadap terhadap persentase berat proventrikulus, persentase berat ventrikulus, persentase berat hati, persentase berat pankreas, persentase berat empedu, persentase berat dan panjang usus halus. Berdasarkan hasil penelitian, dapat disimpulkan bahwa penggantian $12,5 \%$ dan $25 \%$ ransum komersial dengan tepung limbah kecambah kacang hijau difermentasi meningkatkan persentase berat tembolok, tetapi memberikan hasil yang sama terhadap persentase berat proventrikulus, persentase berat ventrikulus, persentase berat hati, persentase berat pankreas, persentase berat empedu, persentase berat dan panjang usus halus.
\end{abstract}

\section{Kata kunci : Limbah kecambah kacang hijau, itik bali jantan, fermentasi, sistem pencernaan}

\section{Effect of Replacement of Commercial Ration with Mung Bean Sprout Waste Flour to the Male Bali Duck Digestion System}

\begin{abstract}
Waste of mung bean sprouts is a part of mung bean sprouts that are not utilized in the production process, even usually wasted. This study aims to determine the effect of replacement of commercial rations with fermented mung bean sprout flour on the digestive
\end{abstract}


system of male Bali ducks. This study uses a completely randomized design (CRD) with three treatments and five replications. The treatment given is; P0 (100\% commercial ration), P1 (replacement of $12.5 \%$ commercial ration with fermented mung bean sprout flour) and P2 (replacement of $25 \%$ commercial ration with fermented mung bean sprout waste flour). The variables observed in this study were percentage of crop weight, percentage of proventriculus weight, percentage of ventricular weight, percentage of liver weight, percentage of pancreatic weight, percentage of bile weight, percentage of small intestine weight and length of small intestine. The results showed that the replacement $12.5 \%$ and $25 \%$ of commercial rations with fermented mung bean sprouts flour significantly $(\mathrm{P}<0.05)$ increased the percentage of crop weight with $\mathrm{P} 1$ and $\mathrm{P} 2$ respectively by $40.90 \%$ and $86.36 \%$ higher than the commercial ration treatment $100 \%(\mathrm{P} 0)$, but not significantly different $(\mathrm{P}>0.05)$ to the percentage of percentage of proventriculus weight, percentage of ventricular weight, percentage of liver weight, percentage of pancreatic weight, percentage of bile weight, percentage of small intestine weight and length of small intestine. Based on the results of the study, it can be concluded that the replacement of $12.5 \%$ and $25 \%$ commercial rations with fermented mung bean sprouts flour increases the percentage of crop weight, but gives the same results to the percentage of proventriculus weight, percentage of ventricular weight, percentage of liver weight, percentage of pancreatic weight, percentage of bile weight, percentage of small intestine weight and length of small intestine.

\section{Key word $\quad$ : Waste of green bean sprouts, male bali ducks, fermentation, digestive system}

\section{PENDAHULUAN}

Itik Bali (Anas sp) adalah salah satu plasma nutfah ternak lokal Indonesia yang banyak dibudidayakan didaerah Bali dan Lombok, itik bali perlu dilestarikan dan dikembangkan supaya keberadaannya tidak punah (Siti, 2016). Sesuai dengan namanya, itik ini banyak ditemui di Bali dan beberapa daerah lain di Indonesia. Itik bali merupakan jenis unggas yang biasa dimanfaatkan sebagai penghasil telur dan daging. Itik bali yang biasanya dimanfaatkan sebagai penghasil daging adalah yang jantan atau betina afkir. Itik bali mempunyai keunggulan yang kurang lebih sama dengan itik-itik lokal lainnya, namun yang membedakan itik bali dengan itik-itik lokal lainnya yaitu adanya jambul pada itik jantannya.

Pakan merupakan salah satu faktor penting penunjang keberhasilan beternak itik selain faktor genetik dan manajemen pemeliharaan. Pakan berfungsi sebagai pembangunan dan pemeliharaan tubuh, sumber energi, produksi, dan pengatur proses-proses dalam tubuh. Komponen pakan yang dimanfaatkan oleh ternak disebut zat gizi (Tillman et al., 1999). Dalam pemeliharaan itik, pakan menjadi kendala utama dalam proses pemeliharaan. Dan hal tersebut dikarenakan harga pakan yang relatif tinggi sehingga peternak harus mengeluarkan biaya lebih besar dalam pemeliharaan. Menurut Yadnya et al. (2014), biaya pakan dapat 
mencapai $60 \%$ dari total biaya produksi. Tingginya biaya untuk pakan ini menyebabkan timbulnya upaya untuk menekan biaya pakan dengan menggunakan pakan alternatif. Salah satu upaya alternatif untuk menekan harga pakan yaitu dengam mengganti ransum dengan menggunakan limbah kecambah kacang hijau.

Limbah kecambah kacang hijau merupakan bagian dari kecambah kacang hijau yang sudah tidak dimanfaatkan lagi dalam proses produksi, bahkan biasanya terbuang sia-sia. Menurut Yulianto (2010), kandungan nutrisi kulit kecambah kacang hijau meliputi bahan kering 88,5\%, protein kasar 13,56\%, serat kasar 33,07\%, lemak kasar 0,22\% dan TDN 64,58\%. Limbah kecambah kacang hijau adalah jenis leguminosa yang mengandung protein tinggi yang baik untuk pertumbuhan, disisi lain serat kasar yang tinggi menjadi pembatas penggunaan dalam ransum unggas. Kebutuhan serat pakan pada beberapa jenis unggas berbeda-beda tergantung jenisnya, puyuh maksimal 7\%, itik maksimal $8 \%$ sedangkan ayam pedaging maksimal 6\% (SNI, 2006). Serat kasar dibutuhkan ternak untuk merangsang gerakan saluran pencernaan, pada ternak ruminansia serat kasar digunakan sebagai sumber energi tetapi pada unggas pemanfaatannya sangat terbatas. Sehubungan dengan hal tersebut, upaya fermentasi terhadap limbah kecambah kacang hijau, akan dapat meningkatkan mutu bahan pakan dan menyederhanakan senyawa yang ada didalamnya. Menurut Kompiang et al. (1994), teknologi untuk meningkatkan mutu bahan pakan adalah dengan fermentasi. Secara umum semua produk akhir fermentasi biasanya mengandung senyawa yang lebih sederhana dan mudah dicerna dibandingkan dengan bahan asalnya (Laelasari dan Purwadaria, 2004).

Penelitian tentang penggunaan limbah kecambah kacang hijau sudah pernah dilakukan, diantaranya adalah Aprilianti et al. (2017) menyatakan bahwa penggunaan tepung limbah kecambah kacang hijau dalam ransum sampai taraf $15 \%$ belum meningkatkan kecernaan protein kasar, kecernaan serat kasar dan pertambahan bobot badan pada itik magelang jantan. Puspitasary et al. (2018) menyatakan bahwa, pemberian pakan yang mengandung limbah kecambah kacang hijau yang difermentasi dalam ransum sampai $15 \%$ tidak mempengaruhi konsumsi ransum, pertambahan bobot badan, dan konversi ransum itik lokal. Dari penelitian tersebut, peneliti mencoba untuk melakukan penelitian menggunakan tepung limbah kecambah kacang hijau difermentasi sebanyak $12,5 \%$ dan $25 \%$ pada itik bali jantan.

Berdasarkan hal tersebut penggantian ransum komersial dengan tepung limbah kecambah kacang hijau difermentasi perlu dilakukan untuk mengkaji pengaruh penggantian 
ransum komersial dengan tepung limbah kecambah kacang hijau difermentasi terhadap sistem pencernaan itik bali jantan umur 8 minggu.

\section{Ternak Itik}

\section{MATERI METODE}

Itik yang digunakan dalam penelitian ini adalah itik bali jantan berjumlah 45 ekor dengan bobot badan 43,8 g \pm 0,96 g. Bibit itik bali ini akan diperoleh dari peternakan UD. Erna beralamat di Kediri, Kabupaten Tabanan.

\section{Kandang dan Perlengkapan}

Kandang yang digunakan adalah kandang Batery Colony sebanyak 15 petak, kerangka utama dari bambu dengan ukuran kandang panjang $80 \mathrm{~cm}$, lebar $65 \mathrm{~cm}$ dan tinggi $50 \mathrm{~cm}$. Alas kandang terbuat dari kawat dengan jarak dari lantai $57 \mathrm{~cm}$, lantai bangunan kandang terbuat dari beton dan atap bangunan kandang terbuat dari asbes. Semua petak kandang berada dalam bangunan yang berukuran $8 \mathrm{~m}$ x $5 \mathrm{~m}$, membujur dari timur ke barat. Setiap petak kandang dilengkapi dengan tempat pakan yang terbuat dari pipa paralon dengan ukuran $40 \mathrm{~cm}$ dan tempat minum terbuat dari botol air mineral berukuran 1,5 liter. Dibawah tempat pakan diletakkan selembar plastik untuk menampung ransum yang jatuh. Untuk mengurangi bau, kelembaban dan memudahkan pembersihan kandang akibat kotoran itik, maka lantai diberi sekam yang diganti setiap tiga hari sekali.

\section{Ransum dan Air Minum}

Ransum yang digunakan terdiri dari ransum komersial CP 511 dan tepung limbah kecambah kacang hijau difermentasi. Air minum yang digunakan adalah air yang berasal dari PDAM. Komposisi bahan penyusun ransum dapat dilihat pada Tabel 2.1, dan komposisi zat makanan dalam ransum percobaan dapat dilihat pada Tabel 2.2.

Tabel 1 Komposisi bahan penyusun ransum

\begin{tabular}{lccc}
\hline & \multicolumn{3}{c}{ Perlakuan $^{1)}$} \\
\cline { 2 - 4 } Komposisi Ransum (\%) & P0 & P1 & P2 \\
\hline RK CP 511 $^{2)}$ & 100 & 87,5 & 75 \\
TLKKHF $^{3)}$ & 0 & 12,5 & 25 \\
\hline Total & 100 & 100 & 100 \\
\hline Kal
\end{tabular}

Keterangan:

1) P0 : Ransum kontrol tanpa tepung limbah kecambah kacang hijau difermentasi.

P1 : Ransum mengandung 12,5\% tepung limbah kecambah kacang hijau difermentasi.

P2 : Ransum mengandung 25\% tepung limbah kecambah kacang hijau difermentasi.

2) RK CP 511 : Ransum Komersial Charoen Pokphand 511.

3) TLKKHF : Tepung Limbah Kecambah Kacang Hijau Difermentasi. 
Tabel 2 Komposisi zat makanan dalam ransum percobaan

\begin{tabular}{lccccc}
\multirow{2}{*}{$\begin{array}{c}\text { Kandungan } \\
\text { Nutrien }\end{array}$} & & \multicolumn{3}{c}{ Perlakuan $^{1)}$} & \multirow{2}{*}{ Standar $^{2)}$} \\
\cline { 3 - 5 } & & $\mathrm{P} 0$ & $\mathrm{P} 1$ & $\mathrm{P} 2$ & \\
\hline Energi Metabolis & $(\mathrm{Kkal} / \mathrm{kg})$ & $3100^{3)}$ & 3023,5 & 2947 & Min. 2700 \\
Protein Kasar & $(\%)$ & 22 & 20,95 & 19,91 & Min. 18 \\
Lemak Kasar & $(\%)$ & 7 & 6,21 & 5,41 & 7,0 \\
Serat Kasar & $(\%)$ & 4 & 9,35 & 14,71 & 8,0 \\
Kalsium (Ca) & $(\%)$ & 0,9 & 0,84 & 0,77 & $0,9-1,2$ \\
Fospor $(\mathrm{P})$ & $(\%)$ & 0,6 & 0,57 & 0,55 & $0,6-1,0$ \\
\hline
\end{tabular}

Keterangan :

1) P0 : Ransum kontrol tanpa tepung kulit kecambah kacang hijau difermentasi.

P1 : Ransum mengandung 12,5\% tepung kulit kecambah kacang hijau difermentasi.

P2 : Ransum mengandung 25\% tepung kulit kecambah kacang hijau difermentasi.

2) Standar Nasional Indonesia 2008.

3) Kandungan zat - zat makanan dari ransum komersial Charoen Pokphand 511.

\section{Peralatan}

Alat-alat yang digunakan dalam penelitian ini, yaitu alat tulis untuk mencatat setiap kegiatan yang dilaksanakan dari awal pemeliharaan sampai akhir pemotongan ternak; timbangan elektrik $5 \mathrm{~kg}$ dengan kepekaan $1 \mathrm{~g}$ yang digunakan untuk menimbang berat badan itik, bahan-bahan penyusun ransum, dan sisa ransum; baskom yang berukuran sedang untuk mencampur ransum, kantong plastik untuk tempat perlakuan ransum; gelas ukur 1 liter untuk mengukur volume air dan sisa air; ember yang berukuran besar untuk menampung air dan sisa air; lembaran plastik dan nampan diletakan dibawah tempat makan dan minum untuk menampung pakan dan air yang berjatuhan.

\section{Tempat dan Lama Penelitian}

Penelitian dilaksanakan di Farm Sesetan Fakultas Peternakan Universitas Udayana, Jalan Raya Sesetan Gang Markisa no. 5, Kelurahan Sesetan, Kecamatan Denpasar Selatan, Kota Denpasar, Bali 80223. Penelitian dilaksanakan selama 8 minggu dari bulan Juni Agustus 2019.

\section{Rancangan Percobaan}

Penelitian menggunakan Rancangan Acak Lengkap (RAL) dengan 3 perlakuan dan 5 ulangan. Setiap ulangan menggunakan 3 ekor itik, sehingga total itik yang digunakan adalah 3 x 5 x $3=45$ ekor. Adapun perlakuannya sebagai berikut; P0 (100\% ransum komersial CP511), P1 (penggantian dengan 12,5\% tepung limbah kecambah kacang hijau difermentasi) dan P2 (penggantian dengan 25\% tepung limbah kecambah kacang hijau difermentasi). 


\section{Pengacakan Itik}

Untuk mendapatkan berat badan itik yang homogen, semua itik sebanyak (60 ekor), ditimbang untuk mencari bobot badan rata-rata (x) g dan standar deviasinya. Itik yang digunakan adalah yang memiliki kisaran bobot badan rata-rata 43,8 \pm 0,96 sebanyak 45 ekor. Itik tersebut kemudian dimasukan ke dalam 15 unit kandang secara acak dan masing-masing unit diisi 3 ekor. Selanjutnya dilakukan pengacakan perlakuan.

\section{Pembuatan Tepung Limbah Kacang Hijau Difermentasi}

Limbah kecambah kacang hijau dijemur dibawah sinar matahari hingga kering kemudian digiling sampai halus. Setelah halus, tepung limbah kecambah kacang hijau difermentasi menggunakan EM (Effective Microorganisme) yang telah dicampur dengan molases (Produk CV. Timan Agung), dengan perbandingan $1 \mathrm{~kg}$ tepung limbah kecambah kacang hijau dan $50 \mathrm{cc}$ molasses dan $500 \mathrm{cc}$ air. Kemudian, simpan didalam wadah tertutup rapat dalam keadaaan anaerob (tanpa oksigen). Diamkan selama 3 hari, setelah itu siap untuk dicampur pada ransum.

\section{Pencampuran Ransum}

Sebelum mencampur ransum terlebih dahulu mempersiapkan alat-alat seperti timbangan, wadah plastik dan baskom yang sudah diberi label perlakuan. Pencampuran ransum akan dilakukan dengan cara menimbang bahan penyusun ransum dari bahan jumlahnya paling banyak, dilanjutkan dengan penimbangan bahan yang jumlahnya lebih sedikit. Bahan yang paling banyak ditempatkan paling awal kemudian bahan yang menengah hingga bahan paling sedikit, kemudian diaduk secara silang sampai homogen dan diaduk secara menyeluruh, begitu pula dengan perlakuan berikutnya. Setelah bahan-bahan tercampur rata masukan ransum pada baskom yang telah beri label.

\section{Pemberian Ransum dan Air Minum}

Ransum dan air minum diberikan ad libitum. Tempat pakan diisi 3/4 untuk menghindari ransum tercecer pada saat itik makan.

\section{Prosedur Pemotongan}

Sebelum pemotongan, itik terlebih dahulu dipuasakan \pm 12 jam, akan tetapi air minum tetap diberikan, kemudia ditimbang bobot badannya. Pemotongan ternak dilakukan berdasarkan USDA (United State Departement of Agriculture, 1977) yaitu dengan memotong vena jugularis dan arteri carotis yang terletak antara tulang kepala dengan ruas tulang leher pertama. Darah yang keluar ditampung dengan mangkok dan ditimbang beratnya. Setelah 
ternak dipastikan mati, kemudian dicelupkan kedalam air panas dengan suhu $\pm 65^{\circ} \mathrm{C}$ selama 1-2 menit, selanjutnya dilakukan pencabutan bulu.

\section{Pemisahan Organ Dalam}

Pemisahan organ dalam dilakukan dengan cara membuat irisan dari kloaka ke arah tulang dada. Selanjutnya bagian dada dan perut dibelah, dan organ-organ dalam dikeluarkan kemudian dilakukan pemisahan seperti rempela, hati, empedu, limpa dan jantung. Isi rempela dikeluarkan, demikian pula empedu dipisahkan dari hati (Soeparno, 1992). Semua organ ditimbang beratnya sesuai dengan variabel yang diamati.

\section{Variabel yang Diamati}

Variabel yang diamati yaitu: 1) persentase berat tembolok, 2) persentase berat proventrikulus, 3) persentase berat ventrikulus, 4) persentase berat organ pembantu pencernaan (hati, pankreas dan empedu), serta 5) persentase berat dan panjang usus halus.

\section{Analisis Data}

Data penelitian dianalisis dengan sidik ragam dan apabila menunjukkan perbedaan yang nyata $(\mathrm{P}<0,05)$ diantara perlakuan, maka analisis dilanjutkan dengan uji jarak berganda Duncan (Steel dan Torrie, 1993).

\section{HASIL DAN PEMBAHASAN}

Hasil penelitian penggantian ransum komersial dengan tepung limbah kecambah kacang hijau difermentasi menunjukkan bahwa bobot potong itik yang mendapat perlakuan P0 (ransum komersial 100\%) seberat 1454,2 g, P1 (penggantian 12,5\% ransum komersial) seberat 1478,20 g dan P2 (penggantian 25\% ransum komersial) seberat 1445,7 g, secara statistik berbeda tidak nyata $(\mathrm{P}>0,05)$. Data tersaji pada Tabel 3.1.

Penggantian 12,5\% dan 25\% ransum komersial dengan tepung limbah kecambah kacang hijau difermentasi berpengaruh nyata $(\mathrm{P}<0,05)$ terhadap persentase berat tembolok, tetapi berbeda tidak nyata $(\mathrm{P}>0,05)$ terhadap persentase berat proventrikulus, persentase berat ventrikulus, persentase berat hati, persentase berat pankreas, persentase berat empedu, persentase berat dan panjang usus halus. 
Tabel 3 Pengaruh penggantian ransum komersial dengan tepung limbah kecambah kacang hijau difermentasi terhadap sistem pencernaan itik bali jantan

\begin{tabular}{|c|c|c|c|c|}
\hline \multirow[t]{2}{*}{ Variabel } & \multicolumn{3}{|c|}{ Perlakuan ${ }^{1)}$} & \multirow[t]{2}{*}{ SEM $^{3)}$} \\
\hline & $\mathrm{P} 0$ & P1 & $\mathrm{P} 2$ & \\
\hline Berat potong (g/ekor) & $1454,2^{\mathrm{a} 2)}$ & $1478,20^{\mathrm{a}}$ & $1445,74^{\mathrm{a}}$ & 35,25 \\
\hline Tembolok (\%) & $0,22^{\mathrm{a}}$ & $0,31^{\mathrm{b}}$ & $0,41^{\mathrm{c}}$ & 0,02 \\
\hline Proventrikulus (\%) & $0,60^{\mathrm{a}}$ & $0,63^{\mathrm{a}}$ & $0,59^{\mathrm{a}}$ & 0,01 \\
\hline Ventrikulus (\%) & $3,00^{\mathrm{a}}$ & $3,06^{\mathrm{a}}$ & $3,19^{\mathrm{a}}$ & 0,08 \\
\hline Hati $(\%)$ & $3,13^{\mathrm{a}}$ & $3,14^{\mathrm{a}}$ & $3,16^{\mathrm{a}}$ & 0,02 \\
\hline Pankreas (\%) & $0,29^{\mathrm{a}}$ & $0,28^{\mathrm{a}}$ & $0,21^{\mathrm{a}}$ & 0,01 \\
\hline Empedu (\%) & $0,19^{\mathrm{a}}$ & $0,19^{\mathrm{a}}$ & $0,21^{\mathrm{a}}$ & 0,01 \\
\hline Persentase usus halus (\%) & $1,67^{\mathrm{a}}$ & $1,31^{\mathrm{a}}$ & $1,61^{\mathrm{a}}$ & 0,06 \\
\hline Panjang usus halus (cm/ekor) & $143,40^{\mathrm{a}}$ & $137,70^{\mathrm{a}}$ & $148,20^{\mathrm{a}}$ & 2,73 \\
\hline
\end{tabular}

Keterangan :

1) P0 : Itik yang diberi ransum komersial $100 \%$

P1 : Penggantian 12,5\% ransum komersial dengan tepung limbah kecambah kacang hijau fermentasi.

P2 : Penggantian 25\% ransum komersial dengan tepung limbah kecambah kacang hijau fermentasi.

2) Superskrip yang sama pada baris yang sama menunjukan tidak berbeda nyata $(\mathrm{P}>0,05)$.

3) SEM (Standart Error of the Treatment Means).

\section{Persentase berat tembolok}

Rataan persentase berat tembolok pada itik yang mendapat perlakuan ransum komersial $100 \%$ (P0) adalah $0,22 \%$ dari berat potong (Tabel 3.1.), sedangkan perlakuan penggantian $12,5 \%(\mathrm{P} 1)$ dan $25 \%(\mathrm{P} 2)$ ransum komersial dengan tepung limbah kecambah kacang hijau difermentasi masing-masing sebesar 40,90\% dan $86,36 \%$ berbeda nyata $(\mathrm{P}<0,05)$ lebih tinggi dari itik yang mendapat perlakuan ransum komersial 100\% (P0). Itik yang mendapatkan penggantian 25\% ransum komersial dengan tepung limbah kecambah kacang hijau difermentasi (P2) adalah $32,36 \%$ berbeda nyata $(\mathrm{P}<0,05)$ lebih tinggi dibandingkan penggantian 12,5\% ransum komersial dengan tepung limbah kecambah kacang hijau difermentasi (P1).

Tembolok adalah organ elastis setelah kerongkongan (Oesophagus) yang berfungsi untuk menyimpan pakan sementara, terutama pada saat unggas makan dalam jumlah banyak. Dalam tembolok sedikit bahkan tidak terjadi proses pencernaan, kecuali pencampuran sekresi saliva dari mulut yang dilanjutkan aktifitasnya di tembolok (Yuwanta, 2004). Persentase berat tembolok yang diperoleh selama penelitian yaitu P0, P1 dan P2 adalah 0,22\%, 0,31\% dan $0,41 \%$ dari berat potong (Tabel 3), secara statistik berbeda nyata $(\mathrm{P}<0,05)$. Penggantian ransum komersial dengan tepung limbah kecambah kacang hijau difermentasi meningkatkan persentase berat tembolok. Hal ini dikarenakan kandungan energi dan protein yang rendah sedangkan kandungan serat kasar sangat tinggi dalam ransum fermentasi dapat menyebabkan 
lambatnya kecernaan ransum sehingga pakan lama mengendap didalam tembolok sehingga kerja tembolok semakin berat. Menurut Prawitasari et al. (2012) menyatakan bahwa kandungan serat kasar ransum mempengaruhi kecernaan serat kasar ransum. Kandungan serat kasar berbanding terbalik dengan kecernaannya. Hal ini sesuai dengan pendapat Hidanah et al. (2013) yang menyatakan bahwa kandungan serat kasar yang semakin tinggi menyebabkan kecernaannya semakin rendah karena ransum yang mengandung serat kasar tinggi akan dicerna lebih lambat dan lebih sedikit dibandingkan dengan ransum yang mengandung sedikit serat kasar.

\section{Persentase berat proventrikulus}

Hasil penelitian menunjukkan bahwa persentase berat proventrikulus itik bali jantan pada perlakuan ransum komersial 100\% (P0) adalah 0,60\% dari berat potong (Tabel 3), sedangkan perlakuan penggantian $12,5 \%(\mathrm{P} 1)$ dan $25 \%$ (P2) ransum komersial dengan tepung limbah kecambah kacang hijau difermentasi masing-masing sebesar 5\% lebih tinggi dan 1,67\% lebih rendah dari itik yang mendapat perlakuan ransum komersial 100\% (P0), namun secara statistik berbeda tidak nyata $(\mathrm{P}>0,05)$. Itik yang mendapatkan penggantian $25 \%$ ransum komersial dengan tepung limbah kecambah kacang hijau difermentasi (P2) adalah $6,35 \%$ lebih rendah dibandingkan penggantian 12,5\% ransum komersial dengan tepung limbah kecambah kacang hijau difermentasi (P1), namun secara statistik berbeda tidak nyata $(\mathrm{P}>0,05)$.

Proventrikulus merupakan pelebaran dari bagian belakang oesophagus dan tempat terjadinya sekresi enzim-enzim pencernaan (pepsinogen dan HCL). Didalam proventrikulus makanan mulai dicerna, namun perannya sangat kecil karena makanan hanya tinggal sebentar didalam organ ini (Akoso, 1998). Dari hasil penelitian ini didapatkan persentase berat proventrikulus pada perlakuan P0, P1 dan P2 masing-masing sebesar 0,60\%, 0,63\% dan 0,59\% dari berat potong (Tabel 3), secara statistik berbeda tidak nyata $(\mathrm{P}>0,05)$. Hal ini disebabkan oleh enzim-ezim yang dihasilkan dalam proventrikulus tidak banyak peranannya karena pakan sudah difermentasi sehingga persentase proventrikulus jadinya sama dengan kontrol (P0). Besar kecilnya proventrikulus dipengaruhi oleh pakan ternak, semakin banyak fitat dalam ransum akan mempengaruhi ukuran proventrikulus, karena proventrikulus bekerja memproduksi asam hydrochloric (HCL) dan pepsin serta enzim yang dapat memecah protein dan serat kasar pada pakan (Amirullah, 2004). Tossaporn (2013) menyatakan bahwa tidak ada pengaruh perbedaan serat kasar terhadap proventikulus. 


\section{Persentase berat ventrikulus}

Rataan persentase berat ventrikulus pada itik yang mendapat perlakuan ransum komersial 100\% (P0) adalah 3,00\% dari berat potong (Tabel 3), sedangkan perlakuan penggantian $12,5 \%(\mathrm{P} 1)$ dan $25 \%(\mathrm{P} 2)$ ransum komersial dengan tepung limbah kecambah kacang hijau difermentasi masing-masing sebesar $2,00 \%$ dan $6,33 \%$ berbeda tidak nyata $(\mathrm{P}>0,05)$ lebih tinggi dari itik yang mendapat perlakuan ransum komersial 100\% (P0). Itik yang mendapatkan penggantian 25\% ransum komersial dengan tepung limbah kecambah kacang hijau difermentasi $(\mathrm{P} 2)$ adalah $4,25 \%$ berbeda tidak nyata $(\mathrm{P}>0,05)$ lebih tinggi dibandingkan penggantian 12,5\% ransum komersial dengan tepung limbah kecambah kacang hijau difermentasi (P1).

Ventrikulus atau gizzard merupakan ruang sederhana yang berfungsi sebagai tempat penyimpanan makanan yang terdiri atas serabut otot yang kuat (Tillman et al., 1991). Pakan dalam gizzard mengalami proses pencernaan secara mekanik dengan bantuan grit yang berupa batuan kecil, selain itu pakan juga akan dipecah dan dicampur dengan air sehingga menjadi seperti pasta atau yang biasa disebut dengan chymne (Kartadisastra, 2002). Persentase berat ventrikulus yang diperoleh pada perlakuan P0, P1 dan P2 masing-masing adalah 3,00\%, 3,06\% dan 3,19\% dari bobot potong (Tabel 3), secara statistik berbeda tidak nyata ( $>>0,05)$. Hal ini diduga fermentasi membantu memudahkan pemecahan serat kasar dalam pakan sehingga kinerja ventrikulus tidak berat dan persentase ventrikulus akhirnya sama dengan perlakuan kontrol (P0). Hasil persentase berat ventrikulus lebih tinggi dari penelitian Ukim et al. (2012) yang berkisar antara 2,07-2,31\%. Menurut Sumiati dan Sumirat (2003) peningkatan bobot ventrikulus disebabkan karena ventrikulus bekerja lebih berat untuk mencerna pakan yang mengandung serat kasar yang tinggi, sehingga kerja ventrikulus semakin berat. Hal ini selaras dengan pendapat Chinajariyawong et al. (2011) yang menyatakan terjadi peningkatan bobot gizard seiring peningkatan serat kasar.

\section{Persentase berat hati}

Hasil penelitian menunjukkan bahwa persentase berat hati itik bali jantan pada perlakuan ransum komersial 100\% (P0) adalah 3,13\% dari berat potong (Tabel 3), sedangkan perlakuan penggantian $12,5 \%(\mathrm{P} 1)$ dan $25 \%(\mathrm{P} 2)$ ransum komersial dengan tepung limbah kecambah kacang hijau difermentasi masing-masing sebesar 0,32\% dan 0,96\% lebih tinggi dari itik yang mendapat perlakuan ransum komersial 100\% (P0), namun secara statistik berbeda tidak nyata $(\mathrm{P}>0,05)$. Itik yang mendapatkan penggantian $25 \%$ ransum komersial dengan tepung limbah kecambah kacang hijau difermentasi (P2) adalah 0,96\% lebih tinggi 
dibandingkan penggantian 12,5\% ransum komersial dengan tepung limbah kecambah kacang hijau difermentasi (P1), namun secara statistik berbeda tidak nyata $(\mathrm{P}>0,05)$.

Hati merupakan organ dalam yang berfungsi penting untuk aktivitas metabolisme detoksifikasi zat-zat yang masuk ke dalam tubuh terutama zat-zat yang bersifat toksik. Persentase berat hati yang diperoleh pada perlakuan P0, P1 dan P2 masing-masing adalah 3,13\%, 3,14\% dan 3,16\% dari bobot potong (Tabel 3), secara statistik berbeda tidak nyata $(\mathrm{P}>0,05)$. Peningkatan serat dan penggunaan kulit kecambah kacang hijau difermentasi diduga tidak mengganggu metabolisme dan menimbulkan keracunan sehingga tidak berpengaruh terhadap fungsi hati. Hal ini dapat dilihat dari persentase hati tidak berbeda nyata antara ketiga perlakuan. Hati berperan sebagai pusat metabolisme zat dan penawar racun sedangkan pangkreas bekerja dalam menghasilkan enzim pencernaan. Hal serupa dilaporkan oleh Dewi et al. (2019) menyatakan bahwa tidak ada tanda-tanda keracunan dan zat antinutrisi akibat penambahan probiotik Effective Microorganisme-4 kedalam air minum itik bali jantan. Jamal (2005), yang mengemukakan bahwa peningkatan jumlah serat akibat penggunaan bungkil zaitun tidak berpengaruh terhadap hati dan jantung. Hasil penelitian ini tidak berbeda jauh dengan penelitian Retnani et al. (2009) yang berkisar antara 2,7-2,9\% dari bobot hidup.

\section{Persentase berat pankreas}

Rataan persentase berat pankreas pada itik yang mendapat perlakuan ransum komersial 100\% (P0) adalah 0,29\% dari berat potong (Tabel 3), sedangkan perlakuan penggantian $12,5 \%(\mathrm{P} 1)$ dan $25 \%(\mathrm{P} 2)$ ransum komersial dengan tepung limbah kecambah kacang hijau difermentasi masing-masing sebesar 3,45\% dan $27,59 \%$ berbeda tidak nyata $(\mathrm{P}>0,05)$ lebih rendah dari itik yang mendapat perlakuan ransum komersial 100\% (P0). Itik yang mendapatkan penggantian 25\% ransum komersial dengan tepung limbah kecambah kacang hijau difermentasi $(\mathrm{P} 2)$ adalah $25,00 \%$ berbeda tidak nyata $(\mathrm{P}>0,05)$ lebih rendah dibandingkan penggantian 12,5\% ransum komersial dengan tepung limbah kecambah kacang hijau difermentasi (P1).

Pankreas merupakan salah satu organ pelengkap sistem pencernaan selain hati dan kelenjar empedu (North dan Bell, 1990). Pankreas mensekresikan enzim amilase, tripsin, lipase untuk membantu pencernaan karbohidrat, protein dan lemak (Blackly dan Bade, 1991). Persentase berat pankreas yang diperoleh pada perlakuan P0, P1 dan P2 masing-masing adalah $0,29 \%, 0,28 \%$ dan $0,21 \%$ dari bobot potong (Tabel 3), secara statistik berbeda tidak 
nyata $(\mathrm{P}>0,05)$. Hasil penelitian menunjukkan bahwa penggantian ransum komersial dengan tepung limbah kecambah kacang hijau difermentasi tidak mempengaruhi persentase bobot pankreas. Hal ini diduga karena pankreas hanya merupakan organ pelengkap pencernaan dan tidak memiliki peranan secara mekanis dalam proses pencernaan. Hal ini selaras dengan penelitian North dan Bell (1990) yang menyatakan pankreas hanya merupakan salah satu organ pelengkap sistem pencernaan, sehingga pengaruh pemberian silase dengan kadar air yang berbeda tidak terlalu berpengaruh nyata terhadap organ pankreas.

\section{Persentase berat empedu}

Hasil penelitian menunjukkan bahwa persentase berat empedu itik bali jantan pada perlakuan ransum komersial 100\% (P0) adalah 0,19\% dari berat potong (Tabel 3), sedangkan perlakuan penggantian $12,5 \%(\mathrm{P} 1)$ dan $25 \%(\mathrm{P} 2)$ ransum komersial dengan tepung limbah kecambah kacang hijau difermentasi masing-masing sebesar 1,06\% dan 11,70\% lebih tinggi dari itik yang mendapat perlakuan ransum komersial 100\% (P0), namun secara statistik berbeda tidak nyata $(\mathrm{P}>0,05)$. Itik yang mendapatkan penggantian $25 \%$ ransum komersial dengan tepung limbah kecambah kacang hijau difermentasi (P2) adalah 10,53\% lebih tinggi dibandingkan penggantian 12,5\% ransum komersial dengan tepung limbah kecambah kacang hijau difermentasi (P1), namun secara statistik berbeda tidak nyata $(\mathrm{P}>0,05)$.

Empedu merupakan organ yang berfungsi sebagai penyalur cairan empedu yang berwarna kuning kehijauan dari hati ke usus dengan pembesaran saluran empedu membentuk kantong empedu (Amirullah, 2004). Persentase berat empedu yang diperoleh pada perlakuan P0, P1 dan P2 masing-masing adalah 0,19\%, 0,19\% dan 0,21\% dari bobot potong (Tabel 3), secara statistik berbeda tidak nyata $(\mathrm{P}>0,05)$. Berat empedu dipengaruhi oleh banyaknya cairan yang dikeluarkan oleh empedu di hati, karena semakin berat kerja hati maka cairan empedu yang dihasilkan semakin banyak dan ukuran kantong empedu semakin besar. Yusuf (2007) menyatakan bahwa meningkatnya kerja organ hati menyebabkan kebutuhan cairan empedu yang lebih banyak, sehingga memacu peningkatan bobot kantong empedu yang dihasilkan.

\section{Persentase berat dan panjang usus halus}

Rataan persentase berat usus halus pada itik yang mendapat perlakuan ransum komersial $100 \%$ (P0) adalah 1,67\% dari berat potong (Tabel 3), sedangkan perlakuan penggantian $12,5 \%(\mathrm{P} 1)$ dan $25 \%(\mathrm{P} 2)$ ransum komersial dengan tepung limbah kecambah kacang hijau difermentasi masing-masing sebesar 21,56\% lebih rendah dan 3,59\% lebih tinggi dari itik yang mendapat perlakuan ransum komersial $100 \%(\mathrm{P} 0)$, tetapi secara statistik 
berbeda tidak nyata $(\mathrm{P}>0,05)$. Itik yang mendapatkan penggantian $25 \%$ ransum komersial dengan tepung limbah kecambah kacang hijau difermentasi (P2) adalah 22,90\% berbeda tidak nyata $(\mathrm{P}>0,05)$ lebih tinggi dibandingkan penggantian $12,5 \%$ ransum komersial dengan tepung limbah kecambah kacang hijau difermentasi (P1). Sedangkan hasil penelitian menunjukkan bahwa panjang usus halus itik bali jantan pada perlakuan ransum komersial $100 \%$ (P0) adalah 143,40 cm (Tabel 3), sedangkan perlakuan penggantian 12,5\% (P1) dan 25\% (P2) ransum komersial dengan tepung limbah kecambah kacang hijau difermentasi masing-masing sebesar 3,97\% lebih rendah dan 3,35\% lebih tinggi dari itik yang mendapat perlakuan ransum komersial 100\% (P0), namun secara statistik berbeda tidak nyata $(\mathrm{P}>0,05)$. Itik yang mendapatkan penggantian 25\% ransum komersial dengan tepung limbah kecambah kacang hijau difermentasi (P2) adalah 7,63\% lebih tinggi dibandingkan penggantian 12,5\% ransum komersial dengan tepung limbah kecambah kacang hijau difermentasi (P1), namun secara statistik berbeda tidak nyata $(\mathrm{P}>0,05)$.

Usus halus merupakan organ yang berfungsi sebagai tempat penyerapan zat-zat makanan, membran mukosa pada usus halus dan memproduksi mucin, $\alpha$-amilase, maltase, sukrase dan juga enzim protealisis (McDonald et al., 1995). Persentase berat usus halus yang diperoleh pada perlakuan P0, P1 dan P2 masing-masing adalah 1,67\%, 1,31\% dan 1,61\% dan panjang usus halus yang diperoleh pada perlakuan P0, P1 dan P2 masing-masing adalah $143,40 \mathrm{~cm}, 137,70 \mathrm{~cm}$ dan $148,20 \mathrm{~cm}$ (Tabel 3), secara statistik berbeda tidak nyata $(\mathrm{P}>0,05)$. Dari hasil penelitian ini menunjukkan penggantian ransum komersial dengan tepung limbah kecambah kacang hijau difermentasi tidak mempengaruhi persentase berat dan panjang usus halus. Hal ini dikarenakan kulit kecambah kacang hijau yang difermentasi ikatan serat kasarnya sudah longgar sehingga enzim - enzim yang dihasilkan didalam usus halus tidak banyak bekerja untuk memecah serat pada pakan sehingga kinerja usus menjadi ringan dan pada akhirnya persentase berat dan panjang usus halus sama dengan kontrol (P0). Amirullah (2004) menyatakan bahwa perubahan panjang, tebal dan berat berbagai saluran pencernaan dapat terjadi selama proses perkembangan yang dipengaruhi oleh jenis ransum yang diberikan. Hal tersebut tidak sesuai dengan pendapat Iyayi et al. (2005) yang menyatakan bahwa pakan yang mengandung serat kasar tinggi dapat meningkatkan bobot dan panjang usus. 


\section{SIMPULAN DAN SARAN}

\section{Simpulan}

Berdasarkan hasil penelitian, dapat disimpulkan bahwa penggantian $12,5 \%$ dan $25 \%$ ransum komersial dengan tepung limbah kecambah kacang hijau difermentasi meningkatkan persentase berat tembolok, tetapi memberikan hasil yang sama terhadap persentase berat proventrikulus, persentase berat ventrikulus, persentase berat hati, persentase berat pankreas, persentase berat empedu, persentase berat usus halus dan panjang usus halus.

\section{Saran}

Dari hasil penelitian ini, dapat disarankan kepada peternak bahwa penggantian ransum komersial dengan tepung limbah kecambah kacang hijau difermentasi sampai level $25 \%$ dapat digunakan sebagai pakan alternatif.

\section{UCAPAN TERIMAKASIH}

Perkenankan penulis mengucapkan terimakasih yang sebesar-besarnya kepada Rektor Universitas Udayana Prof. Dr.dr. A.A. Raka Sudewi, Sp.S(K), Dekan Fakultas Peternakan Dr. Ir. I Nyoman Tirta Ariana, MS, Koordinator Program Studi Sarjana Peternakan Dr. Ir. Ni Wayan Siti, M.Si, atas kesempatan dan fasilitas yang diberikan kepada penulis untuk mengikuti dan menyelesaikan pendidikan di Program Studi Sarjana Peternakan, Fakultas Peternakan, Universitas Udayana. Penulis mengucapkan terimakasih kepada Ibu Ir. Ida Ayu Putri Utami, M.Si.; Ir. Ni Made Artiningsih Rasna, M.Si.; Bapak Ir. Anthonius Wayan Puger, MS.; dan Ibu Dr. Eny Puspani, S.Pt., M.Si.; atas berbagai saran dan masukan untuk penyelesaian artikel ini serta Ibu Ir. Tjokorda Istri Putri dan Komang Sri Urdiarni telah memberikan ijin dan meneliti di Laboratorium Sesetan.

\section{DAFTAR PUSTAKA}

Akoso, B. T. 1998. Kesehatan Unggas. Kanisius.Yogyakarta.

Amirullah, I. K. 2004. Nutrisi Ayam Petelur. Cetakan III. Lembaga Satu Gedung Budi, KKP IPB, Bogor.

Aprilianti, E., I. Mangisah, dan V. D. Y. B. Ismadi. 2017. Pengaruh penggunaan limbah kecambah kacang hijau terhadap kecernaan protein kasar, kecernaan serat kasar dan pertambahan bobot badan itik magelang. Fakultas Peternakan dan Pertanian Universitas Diponegoro.

Blackly, J. dan Bade D. H. 1991. Ilmu Peternakan. Edisi Keempat. Gadjah Mada University Press. Yogyakarta. 
Chinajariyawong, Charurat and Niwat Muangkeow. 2011. Carcass yield and visceral organs of broiler chickens fed palm kernel meal or Aspergillus wentii TISTR 3075 fermented palm kernel meal. Walailak J. Sci. \& Tech., 8(2): 175- 185.

Dewi, N. M. A. W., N. W. Siti dan N. M. S. Sukmawati. 2019. Pengaruh pemberian probiotik effective microorganism-4 melalui air minum terhadap berat organ dalam itik bali jantan. Peternakan Topika. 7(2 ): 544 - 558.

Hidanah, S., E.M. Tamrin, D.S. Nazar, dan E. Safitri. 2013. Limbah tempe dan limbah tempe fermentasi sebagai subtitusi jagung terhadap daya cerna serat kasar dan bahan organik pada itik petelur. Agrovet. 2(1): $71-79$

Iyayi, E. A., O. Ogunsola and R. Ijaya. 2005. Effect of three sources of fibre and period of feeding on the performance, carcase measures, organs relative weight and meat quality in Broilers. International Journal of Poultry Science. 4 (9): 695-700.

Jamal, M. Abo Omar. 2005. Carcass composition and visceral organ mass of broiler chicks fed different levels of olive pulp. Journal of The Islamic University of Gaza 13 (2): 7684.

Kartadisastra, H. K. 2002. Pengolahan Pakan Ayam. Kanisius. Yogyakarta.

Kompiang, I. P., A. P. Sinurat, S. Kompiang, T. Purwadaria, dan J. Darma. 1994. Nutrition value of protein enriched cassava: Cassapro. J. Ilmu Ternak dan Veteriner, 4(2): 107112.

Laelasari dan T. Purwadaria. 2004. Pengkajian nilai gizi hasil fermentasi mutan aspergillus niger pada subtrat bungkil kelapa dan bungkil inti sawit. Biodiversitas, 5(2): 48-51.

McDonald, P., R. A. Edwards, J. F. D. Greenhalgh dan C. A. Morgan .1995. Animal Nutrition. 5th Edition. John Wiley dan Sons Inc. New York.

North, M. O. dan D. D. Bell. 1990. Commercial Chicken Production Manual. 4th Edition. An Avi Book, Van Nostrand Reinhold, New York.

Prawitasari, R. H., V. D. Y. B. Ismadi, dan I. Estiningdriati. 2012. Kecernaan protein kasar dan serat kasar serta laju digesta pada ayam arab yang diberi ransum dengan berbagai level Azolla microphylla. Animal agriculture Journal. 1 (1) : 471 - 483.

Puspitasary, D., R. I. Pujaningsih, dan I. Mangisah. 2018. Pengaruh Pemberian Pakan Mengandung Limbah Tauge Kacang Hijau Fermentasi terhadap Konsumsi Ransum, Pertambahan Bobot Badan, dan Konversi Ransum Itik Lokal. Laporan Penelitian. Fakultas Peternakan dan Pertanian Universitas Diponegoro Semarang.

Retnani Y., E. Suprapti, I. Firmansyah, L. Herawati dan R. Mutia. 2009. Pengaruh penambahan zat pewarna dalam ransum ayam broiler terhadap penampilan, persentase berat bursa fabrisius, karkas dan organ dalam. J.Indon.Trop.Anim.Agric., 34 (2): 115121.

Siti, N. W. 2016. Meningkatkan Kualitas Daging Itik dengan Daun Pepaya. Swasta Nulus. Denpasar. 
Soeparno. 1992. Komposisi googlegoo. Buletin Peternakan 16: 6-14.

SNI (Standar Nasional Indonesia) 01-3910-2006. 2006. Pakan Itik Bertelur (Duck Layer). Badan Standardisasi Nasional.

Steel, R. G. D and J. H. Torrie. 1993. Prinsib dan Prosedur Statistika. Suatu Pendekatan Biometric. Penerjemah: sumantri, B. Gramedia Pustaka Umum, Jakarta.

Sumiati dan A. Sumirat. 2003. Persentase bobot saluran pencernaan dan organ saluran pencernaan organ dalam itik lokal (Anas platyrhyncos) jantan yang diberi berbagai taraf kayambang (Salvinia molesta) dalam ransumnya. Med. Pet. 26 (1): 11-16.

Tillman, A. D., H. Hartadi, S. Reksohadiprojo, S. Prawirokusumo. 1999. Ilmu Makanan Ternak Dasar. Gadjah Mada university Press. Yogyakarta.

Tossaporn Incharoen. 2013. Histological adaptations of the gastrointestinal tract of broilers fed diets containing insoluble fiber from rice hull meal . American Journal of Animal and Veterinary Sciences, 8(2): 79-88.

USDA (United State Departement of Agriculture). 1997. Poultry Guiding Manual. U. S. Government Printing Office Washington D. C.

Ukim C.I., Ojewola G S. and Obun C.O., Ndelekwute E.N.2012. Performance and carcass and organ weights of broiler chicks fed graded levels of Acha grains (Digitaria exilis). Journal of Agriculture and Veterinary Science. Volume 1(2): 28-33.

Yadnya, T. G. B, N. G. K. Roni, N. M. S. Sukmawati. 2014. Pengaruh pemberian tepung daun salam (Syzygium polyanthum walp) dalam ransum yang disuplementasi dengan larutan Effective Microorganism-4 (EM-4) melalui air minum terhadap karkas itik bali jantan. Majalah Ilmiah Peternakan. 17(1) : 30:32.

Yulianto, J. 2010. Pengaruh penggunaan kulit kecambah kacang hijau dalam ransum terhadap kecernaan bahan kering dan organik pada kelinci keturunan vlaams reus jantan. Skripsi. Fakultas Pertanian Universitas Sebelas Maret Surakarta.

Yusuf, Z. 2007. Pengaruh pemberian silase ransum komplit terhadap organ dalam itik mojosari albino jantan. Skripsi Program Studi Ilmu Nutrisi dan Makanan Ternak, Fakultas Peternakan Institute Pertanian Bogor, Bogor.

Yuwanta, Tri. 2004. Dasar Ternak Unggas. Kanisius. Yogyakarta. 